\title{
Index Vol. 18, 1987
}

\begin{tabular}{c|c|c|} 
No. & 1 & 2 \\
Month & January & February \\
Issue & H.E. \& P. & Physics \\
& Physics & \\
Pages & $1-20$ & $21-36$
\end{tabular}

Applied Physics, Physics in Industry Advisory Committee, 84

Aspects of non-linear optics, 48-51

Gyratron development, 120-123

Permanent magnets, 93-96

Physics of plasma chemistry, 28-31

Workshops, magnetic-optic recording 75 pyrolytic arrays, low resolution, 103

Astronomy and Astrophysics

Atmospheres of giant planets, comparative evolution, 116-119

Cosmic background anisotropies, 61-64

Dark matter in the Universe, 138-141

Divisional and Section Boards, 85

Halleys comet, 112

European Society, letter and reply, 137

Neutron stars, cooling, 98-101

Supernova, SN 1987 A, 110

Atomic and Molecular Physics

Divisional and Section Boards, 85, 144

Biophysics

Coding of images by the retina, 32-36

Life, liquids and cryo-electron microscopy, 54-56

Condensed Matter Physics

Divisional Board and Section Committees, 60, 115 Heavy fermion compounds, high pressure ordering, $57-60$

Point imperfections, in semiconductors, 142-144

Semimagnetic semiconductors, 90-92

Superconductivity at high temperature, 110, 125

Tunnelling

Finite temperature in reaction theory, 71-74

Point contact spectroscopy, 21-24

Conferences

Advisory Committee, 84

General Conference of EPS, 47, 77, 109-114

Meetings, 37-44, 83, 126-132

Optical Science and Engineering agreement, 68

Uppsala conference of the HEPP Division, 145-147

Weak and EM interactions in nuclei, 25-27

Education

Advisory Committee, 84

General conference, discussion at, 114

European Geotraverse Project, 78-80, 104-108

\section{Authors}

M.J. Adams, 48-51

J. Andersen, 137

G. Altarelli, 145-147

E.R. Cohen, 65-68

J. Dubochet, $54-56$

J.J.M. Franse, 57-60

\begin{abstract}
R. Freeman, 78-80, 104-108

K. Gabathuler, 10-12

R.R. Galazka, 90-92

D. Gauthier, 116-119

D. Givord, 93-96

H. Grabert, 71-74
\end{abstract}

3
March
Meetings
$37-44$

4
April
Physics
$45-60$

5
May
Physics
$61-76$

\begin{tabular}{|c|}
6 \\
June \\
Physics \\
+ Directory \\
$77-92$
\end{tabular}

\section{Principal Subjects}

European Physical Society

Advisory Committees, 84

Associate Members, 83

Collaborating Societies, 76, 62

Council report from Como, 45-47

Delegates to Council, 81

Divisional and Section Boards, $85-86$

Editorial Boards, 86

Executive Commmittee, 46, 81

General Meeting, 21, 124

Report, 114

Rules, 1988, 124

General Conference,

Programme, 77

Report, 109-114

Travel arrangements, 47

Lecturer, 83

Members, 19, 74, 76, 81-82, 115

Unit fee, 47, 133

Workshops

Employment of physicists, 87-88

Magnetic-optic recording, 75

Nuclear winter, 69-70

Pyroelectric arrays, low resolution, 103

Fundamental physical constants, 65-68

Gyratron, high-power microwawe source, 120-123

Hewlett-Packard Europhysics Prize

Award, 1987 to I. Yanson, 19

Point contact spectroscopy, 21-24

Award, 1988 to J.G. Bednorz and K.A. Müller, 125

Call for nominations, 88

High Energy and Particle Physics

Detectors, 7-9

Divisional Board, 85

Evolution of particle accelerators, 4-6

Ideas beyond the standart model, 17-19

Introduction, 1

Properties of neutrinos, 10-12

Quantum gravity and particle physics, 14, 112

Standard theory of particle interactions, 2-4

Uppsala conference of the HEPP Division, 145-147

Inter-Divisional Groups

Computational Physics Board, 86

Experimental Physics Control Systems, Officers, 86

Physics for Development Board, 86

$\begin{array}{ll}\text { M.B. Green, 14-16 } & \text { A.G.M. Jansen, 21-24 } \\ \text { P. Hänggi, 71-74 } & \text { H. van Kempen, 21-24 } \\ \text { A. Howie, 52-53 } & \text { H.V. Klapdor, 25-27 } \\ \text { M.C.E. Huber, 137 } & \text { J.M. Langer, 142-144 } \\ \text { M. Hyland, 133-137 } & \text { D.A.H. Mace, 48-51 } \\ \text { M. Imbert, 32-36 } & \text { L. Maiani, 2-4 } \\ \text { M. Jacob, 123-124 } & \text { B. Melchiorri, 61-64 }\end{array}$

Europhysics News is the official journal of the European Physical Society which comprises 29 National Societies, Academies and Group, about 4000 Individual Members and 75 Associate Members. Governing bo dies of EPS are the General Meeting, Council and an elected Executive Committee responsible for detailed policy. EPS promotes the collaboration of physicists policy. EPS promotes the collaboration of physicists
throughout Europe, organising and harmonising confe rences and publications, improving physics education, encouraging physics applications, awarding scholarships to sponsored schools in Erice. EPS publishes in addition to Europhys. News, Europhysics Letters (in partnership with national societies), European Joumal partnership with national societies), European Journal and European Conference Abstracts. Individual Members receive Europhys. News free of charge (price to insts.: Sw.Fr. 90./a), Europhys. Lett. at Sw.Fr. 125.-/a (insts. 1050-), rebates on many other publications and on conference fees. Annual EPS membership fee for individual Members belonging to an EPS member society dividual Members belonging to an EPS member society members of a Collaborating Society: Sw.Fr. 55.-

\begin{tabular}{c|c|c|c|}
$7 / 8$ & 9 & 10 & $11 / 12$ \\
July/Aug. & September & October & Nov./Dec. \\
Physics & Physics & Meetings & Physics \\
$93-108$ & $109-124$ & $125-132$ & $133-148$
\end{tabular}

Japan, Physical Society of, 82

Sectional meetings, 76

Magnetism

Permanent, rare earth-transition metal, 93-96

Semimagnetic semiconductors, 90-92

Microscopy

Cryo-electron, in life and liquids, 54-56

Electron, punctuated evolution of, 52-53

Scanning-tunnelling, 113-114

Nobel Prize

J.G. Bednorz and K.A. Müller, 1987, 147

E. Ruska, 1986, 52-53

Nuclear Physics

Divisional Board, 85

European Suppression Shield Array, 102

Positron spectrometry, 112

Reactivity coefficients in reactors, 133-137

Weak and electromagnetic interactions in nuclei, 25-27

Optics

Agreement with Europtica and SPIE, 68

Aspects of non-linear optics, 48-51

Divisional Board, 86

Physics and Society

Advisory Committee, 84

Workshops, 69-70, 87-88

Plasma Physics

Divisional Board, 86, 115

JET, 112

Physics of plasma chemistry, 28-31

Prizes, joint in physics 1987, 123-124

Publications

Advisory Committee, 84

Editorial Boards, 86

Europhysics Conference Abstracts, 86

Europhysics Letters, 86, 125

Divisional Board, 86

Helsinki satellite meeting, 76

Went J.J., death of, 31

F. Melchiorri, 61-64

B.W. Montague, 4-6

St. Müller, 78-80, 104-108

H. Ogelman, 98-101

D. Parkinson, 69-70

R.D. Peccei, 17-19

M.J. Rees, 138-141

H. Ryde, 102

D.C. Scharm, 28-31

S. Straessler, 103

B.N. Taylor, $65-68$

M.Q. Tran, 120-123

P. Wyder, 21-24

T. Ypsilantis, 7-9
Quantum Electronics

\section{Editor: E.N. Shaw}

Editorial Board:
A. Baratoff, F. James, M. Lehmann.
M. Mayor, J. Muller, M. Slegrist

Editorial and Advertising Office at the EPS Secretariat

Address: EUROPEAN PHYSICAL SOCIETY

P.O. Box 69 .

CH-1213 Petit-Lancy 2

Switzerland

Telephone: Geneva (22) 931130

Telex: 428024 eps ch

Cables: europhys genève

Printed by: Pfirter frères sa

CH-1213 Petit-Lancy/Switzerland 